\title{
PROFIL KEMAMPUAN PEMECAHAN MASALAH MATEMATIKA SISWA SMP PADA MATERI SEGIEMPAT DITINJAU DARI TIPE KEPRIBADIAN EKSTROVERT-INTROVERT
}

\author{
Watik Aprilia Putri \\ Pendidikan Matematika, Fakultas Matematika dan Ilmu Pengetahuan Alam, Universitas Negeri Surabaya \\ e-mail: watikputri@mhs.unesa.ac.id

\section{Masriyah} \\ Pendidikan Matematika, Fakultas Matematika dan Ilmu Pengetahuan Alam, Universitas Negeri Surabaya \\ e-mail: masriyah@unesa.ac.id
}

\begin{abstract}
Abstrak
Masalah merupakan pertanyaan yang dihadapi ketika tidak dapat diselesaikan dengan prosedur rutin. Untuk menyelesaikan masalah matematika membutuhkan analisis atau prosedur lain. Masalah matematika yang sering dijumpai dalam kehidupan salah satunya yaitu masalah segiempat. Menurut Polya, terdapat empat fase proses pemecahan masalah, yaitu memahami masalah, membuat perencanaan, melaksanakan perencanaan, dan memeriksa kembali. Terdapat salah satu faktor yang memengaruhi kemampuan pemecahan masalah, yaitu kepribadian seseorang yang berbeda. Penelitian ini merupakan penelitian deskriptif kualitatif yang bertujuan mendeskripsikan profil kemampuan pemecahan masalah matematika siswa SMP pada materi segiempat yang mempunyai kepribadian ekstrovert atau introvert. Subjek penelitian terdiri dari dua siswa kelas VII SMP dengan kemampuan matematika yang berbeda, di antaranya satu siswa ekstrovert dan satu siswa introvert. Instrumen yang digunakan adalah tes tipe kepribadian ekstrovertintrovert yang disebut Myer Briggs Type Indicator (MBTI), tes kemampuan matematika, tes pemecahan masalah dan pedoman wawancara. Hasil penelitian menunjukkan bahwa: (1) siswa ekstrovert tidak mampu melakukan keseluruhan tahapan dalam menyelesaikan permasalahan, siswa hanya mampu pada langkah memahami masalah, namun siswa tidak mampu dalam membuat perencanaan, melaksanakan perencanaan, dan memeriksa kembali dan (2) siswa introvert mampu melakukan seluruh tahapan pemecahan dalam menyelesaikan permasalahan, yang mencakup memahami masalah, membuat perencanaan, melaksanakan perencanaan, sampai pada tahap memeriksa kembali.
\end{abstract}

Kata kunci: pemecahan masalah matematika, pemecahan masalah polya, kepribadian ekstrovert, kepribadian introvert

\section{Abstract}

A problem is a question that is encountered when it cannot be solved by routine procedures. To solve a mathematical problems requires analysis or other procedures. One of mathematical problems which is commonly occurred in daily life is quadrilateral problems. According to Polya, there are four phases in the problem-solving process, those are understanding the problem, compiling a plan, carry out a plan, and rechecking. There is one factor that influences the ability of problem solving, that is a someone's different personality. This research used qualitative descriptive study which aimed to describe the profile of junior high school students' ability to solve mathematical problems in quadrilateral in terms of extrovert or introvert personality. The research subjects consisted of two students from seventh graders who have different mathematical abilities, it included an extrovert and an introvert student. The instruments which were used in this study were extrovert-introvert personality type test, called the Myer Briggs Type Indicator (MBTI), mathematical ability test, problem solving test and interview guidelines. The results of this study indicated that: (1) the extrovert students were unable to do the all stages of solving problems, the students are only able to understand the problem, but students were not able to make a plan, carry out a plan, and rechecking and (2) the introvert students were able to carry out all stages of solving in solving problems, which included understanding the problem, make a plan, carry out a plan, until at the stage of re-checking. Keywords : mathematical problem solving, polya problem solving, extrovert personality, introvert personality 


\section{PENDAHULUAN}

Masalah merupakan pertanyaan yang dihadapi seorang individu atau kelompok ketika mereka tidak mempunyai aturan atau prosedur tertentu yang dapat digunakan untuk menentukan jawabannya, dan untuk menyelesaikannya membutuhkan analisis atau prosedur lain (Siswono, 2018). Tidak jarang, cara untuk menyelesaikan masalah tidaklah mudah, melainkan membutuhkan proses yang rumit, yang biasanya dinamakan soal non-rutin. Meskipun tidak semua masalah bersifat matematis, namun seringkali pemikiran matematis memudahkan proses penyelesaian masalah. Dalam pembelajaran matematika juga tidak terlepas dengan adanya masalah. Shadiq (2004:10) mengatakan bahwa suatu pertanyaan akan menjadi masalah jika pertanyaan tersebut menunjukkan adanya suatu tantangan (challenge) yang tidak dapat dipecahkan oleh suatu prosedur rutin (routine procedure) yang sebelumnya sudah diketahui oleh pelaku. Suatu pertanyaan atau soal dapat menjadi masalah bagi sebagian siswa, namun bisa saja bukan menjadi masalah bagi siswa lainnya. Oleh karena itu, setiap siswa mempunyai pandangan yang berbeda mengenai setiap pertanyaan atau soal yang diberikan.

Menurut Polya (1973), terdapat empat fase dalam proses pemecahan masalah, yaitu memahami masalah, membuat perencanaan, melaksanakan perencanaan, dan memeriksa kembali. Fase-fase tersebut akan terus berulang selama masalah belum terpecahkan. Pada proses pemecahan masalah, umumnya siswa menggunakan berbagai macam strategi. Menurut Reys (1978), terdapat sebelas strategi berbeda dalam pemecahan masalah matematika. Strategi yang digunakan tersebut bergantung pada konteks masalah yang dihadapi siswa ketika mendapat soal berupa pemecahan masalah. Pengalaman siswa juga menjadi faktor pemilihan strategi yang dipilih oleh siswa untuk menyelesaikan masalah.

Pada kenyataan di lapangan, saat ini masih banyak siswa di Indonesia yang memiliki tingkat kemampuan pemecahan masalah matematika yang tergolong rendah. Hal ini dibuktikan adanya hasil riset pada PISA (Program for International Student Assessment) tahun 2012 yang membuktikan bahwa kemampuan rata-rata siswa di Negara Indonesia dalam mata pelajaran Matematika dan Sains tergolong sangat rendah. Hal itu selaras dengan penelitian yang dilakukan Trizulfianto (2017) dan Anna (2018) bahwa siswa di Indonesia cenderung mengalami kesulitan ketika menghadapi masalah matematika. Kesulitan yang terjadi adalah ketika siswa sulit menerjemahkan masalah yang diberikan ke dalam bentuk kalimat matematika. Hal itu terjadi karena selama ini pembelajaran di sekolah, siswa cenderung melakukan apa yang dicontohkan guru. Siswa hanya dibekali soal-soal rutin yang tidak banyak memerlukan proses berpikir tingkat tinggi dalam menyelesaikannya. Rahma dan Masriyah (2016) menyatakan bahwa salah satu faktor penyebab rendahnya kemampuan matematika siswa Indonesia yaitu adanya kurikulum pendidikan matematika belum menekankan pada aspek pemecahan masalah, melainkan pada hal-hal yang mempunyai penyelesaian bersifat prosedural, sehingga siswa jarang diberi kesempatan untuk mengembangkan potensinya dalam memecahkan masalah.

Isroil, dkk (2017) menyatakan bahwa dalam memecahkan masalah matematika, setiap individu mempunyai cara dan karakteristik yang berbeda dalam memecahkannya. Perbedaan karakteristik tersebut dapat dipengaruhi oleh banyak faktor. Salah satu faktor yang memengaruhi kemampuan pemecahan masalah yaitu kepribadian seseorang. Pernyataan tersebut sejalan dengan Siskawati (2013) yang mengatakan bahwa kemampuan pemecahan masalah matematika akan berbeda jika kepribadian pada seseorang yang berbeda pula. Tipe kepribadian yang dijelaskan dalam kajian ilmu psikologi oleh Jung dalam (Jaenudin, 2015), bahwa kepribadian seseorang dibagi menjadi dua golongan besar, yaitu tipe kepribadian introvert dan ekstrovert. Soetopo (2012) menyatakan bahwa kebiasaan-kebiasaan yang muncul pada dalam diri seseorang akan memengaruhi bagaimana seseorang bersikap dan bagaimana pula seseorang mengambil keputusan dalam setiap bertindak. Berdasarkan uraian tersebut, dapat disimpulkan bahwa terdapat hubungan antara tipe kepribadian seseorang dengan pemecahan masalah. Jika dikaitkan, tipe kepribadian seseorang turut berperan serta dalam kegiatan pengambilan keputusan untuk memecahkan suatu masalah yang sedang dihadapi. Pernyataan tersebut sejalan dengan penelitian yang dilakukan oleh Hasanah (2013) juga menjelaskan bahwa terdapat perbedaan dalam proses pemecahan masalah pada tipe kepribadian ekstrovert dan kepribadian introvert. Jika seseorang dengan tipe kepribadian introvert, cenderung menyelesaikan masalah secara terstruktur karena seorang introvert akan berpikir untuk merenungkan masalah yang dihadapi, serta lebih sabar dalam bertindak, seseorang tersebut juga dapat menuliskan proses penyelesaian secara rinci. Sementara itu, seseorang dengan tipe kepribadian ekstrovert akan tidak sabar dan cenderung lebih cepat dalam menyelesaikan masalah, namun ketika dihadapkan pada permasalahan matematika, seringkali tidak menuliskan secara rinci kesimpulan yang diperoleh, sehingga penyelesaian cenderung kurang terstruktur dan kurang cermat. Begitu pula dengan siswa, siswa dengan tipe kepribadian yang berbeda juga mempunyai perbedaan strategi dalam memecahkan masalah. Dengan melalui pengenalan kepribadian pada siswa, hal tersebut dapat 
membantu dalam mengetahui kelebihan dan kekurangan pada setiap siswa, sehingga dapat dicari cara-cara terbaik dalam mengatasi kekurangan yang dapat menyebabkan ketidakberhasilan siswa dalam menyelesaikan soal pemecahan masalah.

Materi yang dipilih dalam penelitian ini yaitu materi segiempat pada kelas VII. Menurut Riyeni dan Khabibah (2017), salah satu materi pelajaran yang dianggap susah oleh siswa adalah materi geometri. Pengambilan materi luas dan keliling segiempat disebabkan karena terdapat beberapa kesalahan yang seringkali dilakukan siswa pada saat mengerjakan soal geometri yaitu jika siswa diberikan soal yang tidak sesuai dengan contoh soal yang telah diberikan oleh guru pada saat penyampaian materi, seringkali siswa merasa kesulitan. Seperti saat siswa diberi contoh soal terkait luas dan keliling segiempat, kemudian diberikan lagi soal untuk mencari luas dan keliling maksimum dari bangun tersebut, maka siswa akan mengalami kesulitan. Selain itu materi segiempat adalah salah satu materi pada mata pelajaran matematika yang sering digunakan dalam kehidupan sehari-hari. Materi luas dan keliling segiempat bukanlah materi baru bagi siswa jenjang SMP, karena pada saat duduk di bangku Sekolah Dasar (SD) mereka sudah seringkali menjumpai materi yang berkaitan dengan segiempat, sehingga pengetahuan yang telah dimiliki siswa dapat menjadi bekal dalam penerapan pembelajaran pemecahan masalah.

Dalam penelitian ini, diberikan masalah matematika yang menuntut siswa untuk mencari luas maksimum pada bangun segiempat. Misalnya, sebuah sebidang tanah milik Pak Budi mempunyai keliling sebesar $50 \mathrm{~m}$, tentukan luas maksimum tanah milik Pak Budi tersebut jika setiap sisi pada bidang tanah merupakan bilangan bulat. Maka dengan menerapkan konsep luas dan keliling segiempat, Pak Budi dapat menghitung berapa meter persegi luas tanah yang dimilikinya.

Berdasarkan latar belakang yang telah diuraikan, peneliti tertarik untuk melakukan penelitian yang berjudul "Profil Kemampuan Pemecahan Masalah Matematika Siswa SMP pada Materi Segiempat Ditinjau dari Tipe Kepribadian Ekstrovert-Introvert".

Tujuan dari penelitian ini yaitu untuk mendeskripsikan kemampuan pemecahan masalah matematika siswa SMP pada materi segiempat ditinjau dari tipe kepribadian ekstrovert dan tipe kepribadian introvert.

Berdasarkan pertanyaan penelitian agar dapat menjawab pertanyaan penelitian tersebut, diperlukan pengetahuan terkait teori ahli yang mendukung penelitian, antara lain: langkah pemecahan masalah menurut Polya, tipe kepribadian introvert dan tipe kepribadian ekstrovert.
Pemecahan masalah merupakan keterampilan yang dimiliki seseorang dalam proses menyelesaikan masalah. Pemecahan masalah merupakan hal yang penting di dalam pembelajaran matematika, sebab untuk menyeleksi informasi yang relevan dapat menjadikan siswa lebih terampil, kemudian siswa menganalisa dan memeriksa kembali terhadap hasil yang telah diperoleh. Agar manfaat dari pemecahan masalah dapat diterima secara optimal oleh siswa, maka perlu adanya suatu tahapan yang membantu mereka memecahkan masalah tersebut secara sistematis. Ada banyak cara yang diungkapkan oleh para ahli mengenai tahapan penyelesaian masalah, salah satunya adalah George Polya. Menurut Polya (1973), dalam pemecahan masalah terdapat empat fase yang dilalui seseorang untuk menyelesaikan masalah, yaitu memahami masalah, membuat perencanaan, melaksanakan perencanaan, dan memeriksa kembali. Dalam penelitian ini, tahapan yang digunakan adalah tahapan pemecahan masalah menurut Polya yang cukup sederhana, serta aktivitas pemecahan masalahnya cukup jelas secara eksplisit, sehingga lebih mudah diamati.

Berdasarkan langkah pemecahan masalah menurut Polya, beberapa indikator yang dapat dirumuskan sebagai berikut.

Tabel indikator langkah pemecahan masalah

\begin{tabular}{|c|c|}
\hline $\begin{array}{c}\text { Langkah } \\
\text { pemecahan } \\
\text { masalah }\end{array}$ & Indikator \\
\hline $\begin{array}{r}\text { Mema } \\
\text { masa }\end{array}$ & $\begin{array}{l}\text { 1. Mampu menjelaskan apa yang } \\
\text { diketahui dan ditanyakan } \\
\text { dalam masalah tersebut . } \\
\text { 2. Mampu menjelaskan kondisi } \\
\text { soal terkait hubungan antara } \\
\text { informasi yang diberikan. }\end{array}$ \\
\hline $\begin{array}{c}\text { Membuat } \\
\text { perencanaan }\end{array}$ & $\begin{array}{l}\text { 1. Mampu menemukan dan } \\
\text { memilih informasi-informasi } \\
\text { yang akan digunakan untuk } \\
\text { menjawab pertanyaan yang ada } \\
\text { dengan tepat. } \\
\text { 2. Mampu menjelaskan rencana } \\
\text { penyelesaian yang akan } \\
\text { dilakukan untuk memecahkan } \\
\text { masalah dengan benar. }\end{array}$ \\
\hline $\begin{array}{c}\text { Melaksanakan } \\
\text { perencanaan }\end{array}$ & $\begin{array}{l}\text { 1. Mampu melaksanakan rencana } \\
\text { penyelesaian sesuai dengan } \\
\text { rencana yang telah dibuat } \\
\text { sebelumnya. Jika terjadi } \\
\text { perubahan perencanaan, maka } \\
\text { siswa dapat kembali ke } \\
\text { langkah sebelumnya, yaitu } \\
\text { membuat perencanaan. } \\
\text { 2. Mampu melaksanakan rencana } \\
\text { penyelesaian dengan konsep } \\
\text { yang sesuai. }\end{array}$ \\
\hline
\end{tabular}




\begin{tabular}{|c|l|}
\hline & $\begin{array}{l}\text { 1. } \text { Mampu melakukan } \\
\text { pengecekan kembali terhadap } \\
\text { hasil yang diperoleh untuk } \\
\text { memastikan hasil apakah tepat } \\
\text { Memeriksa } \\
\text { kembali }\end{array}$ \\
& 2. Mampu menyusun suatu \\
& $\begin{array}{l}\text { kesimpulan dari permasalahan } \\
\text { yang diberikan. }\end{array}$ \\
\hline
\end{tabular}

Jung (dalam Djaali, 2014) menjelaskan bahwa kepribadian adalah pola perilaku dan persepsi seseorang dalam bereaksi maupun berinteraksi dengan individu lain, serta dapat menyesuaikan diri terhadap lingkungannya. Kepribadian dibagi menjadi dua tipe, yaitu kepribadian ekstrovert dan kepribadian introvert.

Ekstrovert adalah sikap yang mengarahkan energi psikis keluar sehingga seseorang diorientasikan menuju sesuatu yang objektif dan menjauh dari subjektif (Jaenudin, 2015). Seorang ekstrovert sering dipengaruhi oleh lingkungan sekitar daripada dunia batin mereka. Sifat sosialnya lebih tinggi dan lebih banyak berbuat daripada merenung dan berpikir. Seorang ekstrovert juga mudah bergaul karena memiliki kecepatan beradaptasi dengan lingkungan yang tinggi, mempunyai banyak teman, tidak suka membaca dan belajar sendirian.

Widayanti (2016) mengatakan bahwa terdapat hubungan antara tipe kepribadian dengan kegiatan siswa dalam pemecahan masalah matematika yaitu siswa berkepribadian ekstrovert berbicara melalui ide-ide mereka untuk mengklarifikasinya. Siswa ekstrovert memiliki cara berpikir secara logis matematis, memiliki sikap yang cepat tanggap dan aktif di dalam kegiatan pembelajaran, baik tugas yang dilakukan secara individu maupun secara berkelompok, namun kurang teliti dalam memecahkan masalah yang diberikan.

Introvert adalah membalikkan energi psikis dalam sebuah orientasi terhadap subjektivitas (Jaenudin, 2015). Seorang introvert cenderung pendiam, suka menyendiri, menarik diri dari kontak sosial, menjaga jarak kecuali dengan teman-temannya yang sudah akrab, perhatian dan minatnya lebih terfokus pada pengalaman dan pikirannya sendiri. Seorang berkepribadian introvert seringkali tidak mudah percaya, mudah cemburu, iri hati, serta suka menjalani kehidupan dengan keseriusan. Ciriciri yang lainnya adalah reflektif, bijaksana, tenggang rasa, pemalu, serta cenderung menyukai pola hidup yang teratur dengan baik.

Lebih lanjut, Widayanti (2016) mengatakan bahwa terdapat hubungan antara tipe kepribadian dengan kegiatan siswa dalam pemecahan masalah matematika yaitu siswa berkepribadian introvert yaitu cenderung membutuhkan waktu untuk berpikir dan mengklarifikasi ide-ide mereka sebelum mereka memulai berbicara. Siswa introvert memiliki sikap yang kurang aktif bahkan dapat dikatakan cenderung pasif di dalam kegiatan pembelajaran, baik tugas yang dilakukan secara individu maupun secara berkelompok, namun teliti dan bersungguh-sungguh dalam memecahkan masalah yang diberikan.

Untuk menentukan tipe kepribadian siswa dalam dimensi introvert atau ekstrovert, peneliti menggunakan tes kepribadian Myer Briggs Type Indicator (MBTI) oleh Katharine C. Briggs dan Isabel Briggs (dalam Mudrika, 2011). Dalam soal tes tipe kepribadian terdapat 60 soal masing masing nomor memiliki dua pernyataan (pernyataan A dan pernyataan B) yang keduanya memiliki arti bertolak belakang. Subjek penelitian diminta untuk memilih salah satu pernyataan yang sesuai dengan pribadi masing-masing dan menuliskan checklist pada kolom yang telah tersedia.

Pratiwi (2017) mengatakan bahwa kebiasaan individu dalam mengambil keputusan akan memberi pengaruh terhadap pembelajaran. Hal tersebut dikarenakan dalam memahami materi pembelajaran, seseorang akan mengalami proses berpikir berdasarkan pengalamannya, kemudian seseorang tersebut menyimpulkan terhadap apa yang sudah mereka pelajari dengan dipengaruhi oleh sikap. Selain itu, tipe kepribadian seseorang juga mempunyai andil besar dalam proses pemecahan masalah matematika. Siswa yang memiliki tipe kepribadian berbeda, akan berbeda pula cara mereka dalam memecahkan masalah yang mereka hadapi.

\section{METODE}

Penelitian ini merupakan jenis penelitian deskriptif yang menggunakan pendekatan kualitatif. Hal ini dikarenakan dalam penelitian ini data yang dihasilkan berupa data deskriptif dengan bentuk kata-kata tertulis ataupun lisan dari subjek penelitian yang diamati. Tujuan dari penelitian ini adalah untuk mendeskripsikan kemampuan pemecahan masalah matematika siswa SMP pada materi segiempat ditinjau dari tipe kepribadian ekstrovert dan introvert.

- Subjek penelitian yang dipilih dalam penelitian ini adalah dua siswa kelas VII SMP tahun ajaran 2019/2020 dengan rincian satu siswa berkepribadian ekstrovert dan satu siswa berkepribadian introvert, dengan kriteria subjek yang memiliki selisih hasil tes kemampuan matematika dan tes tipe kepribadian tidak lebih dari lima poin.

Instrumen penelitian yang digunakan dalam penelitian ini yaitu sebagai berikut.

1. Instrumen Utama

Instrumen utama yang digunakan dalam penelitian ini adalah peneliti. Hal ini dikarenakan peneliti berfungsi sebagai pemilih subjek penelitian, 
melakukan pengambian data, menganalisis data, dan menyimpulkan hasil dari penelitian ini.

2. Lembar Tes Kepribadian

Instrumen ini digunakan untuk mengetahui data kelompok siswa tipe kepribadian ekstrovert dan introvert.

3. Lembar Tes Kemampuan Matematika

Instrumen ini digunakan untuk menyeleksi siswa yang akan dijadikan subjek dalam penelitian ini.

4. Lembar Tes Pemecahan Masalah Matematika

Instrumen ini digunakan untuk mendapatkan data tentang kemampuan siswa dalam memecahkan suatu permasalahan matematika yang berkaitan dengan bangun datar segiempat.

5. Wawancara

Wawancara digunakan untuk mendapatkan informasi yang tidak tertulis, serta digunakan untuk mengetahui kejelasan lebih dalam mengenai hasil penyelesaian ketika siswa memecahkan suatu masalah matematika pada materi segiempat yang diberikan.

Pemilihan subjek penelitian dilakukan berdasarkan data tes hasil analisis Tes Kepribadian dan Tes Kemampuan Matematika. Tes Tipe Kepribadian terdiri dari 60 soal yang dikerjakan dalam waktu 15 menit. Sedangkan Tes Kemampuan Matematika terdiri dari dua soal yang berkaitan dengan gabungan dua bangun persegi dan persegi panjang dengan waktu 30 menit. Analisis data Tes Kepribadian dilakukan dengan menggunakan kisi-kisi tes tipe kepribadian MBTI. Analisis data Tes Kemampuan Matematika dilakukan dengan menggunakan pedoman penskoran. Dari hasil analisis data Tes Pemecahan Masalah Matematika dan wawancara akan dideskripsikan dalam bagaimana profil kemampuan pemecahan masalah matematika siswa SMP pada materi segiempat ditinjau dari tipe kepribadian ekstrovert dan introvert.

\section{HASIL DAN PEMBAHASAN}

Berdasarkan analisis data yang telah dilakukan, diperoleh hasil dan pembahasan mengenai profil kemampuan pemecahan masalah matematika siswa SMP pada materi segiempat ditinjau dari tipe kepribadian ekstrovert dan introvert.
1. Profil Kemampuan Pemecahan Masalah Matematika Siswa SMP pada Materi Segiempat Ditinjau dari Tipe Kepribadian Ekstrovert

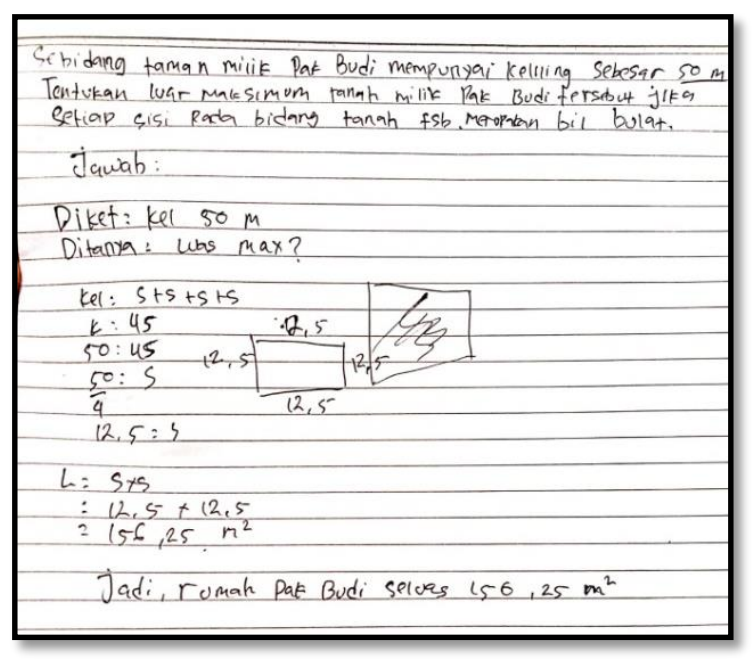

Gambar 1 Hasil Jawaban Siswa Ekstrovert

Petikan wawancara berikut menunjukkan penjelasan siswa ekstrovert pada tahap memahami masalah.

Peneliti : Kamu paham dengan maksud soal itu?

Siswa

Ekstrovert: Iya, saya sudah paham kak.

Peneliti: Berapa kali kamu membaca untuk memahami?

Siswa Tadi saya bacanya dua kali.

Ekstrovert:

Peneliti: Bisa menjelaskan apa saja perintah dalam soal?

Siswa Diminta untuk mencari luas maksimum

Ekstrovert: sebidang tanah yang diketahui kelilingnya.

Berdasarkan hasil tes dan wawancara yang telah dilakukan, hal pertama yang dilakukan siswa ekstrovert ketika mendapatkan soal berupa masalah matematika yaitu memahami soal dengan membaca berulang sebanyak dua kali. Hal tersebut dilakukan siswa ekstrovert agar lebih memahami permasalahan yang diberikan. Siswa ekstrovert mampu menjelaskan bahwa pada soal diminta untuk menentukan luas maksimum jika diketahui kelilingnya. Siswa ekstrovert memenuhi indikator mampu menjelaskan apa yang diketahui dan ditanyakan dalam masalah, yang berarti siswa mampu dalam memahami masalah.

Petikan wawancara berikut menunjukkan penjelasan siswa ekstrovert pada tahap membuat perencanaan.

Peneliti : $\quad$ Kamu sudah pernah menjumpai soal seperti ini?

Siswa Kalau luas keliling segiempat sudah

Ekstrovert: sering mengerjakan kak. Tapi kalau yang ditanyakan luas maksimum, kayaknya baru tahu sekarang.

Peneliti: Bagaimana langkah yang kamu gunakan untuk menjawab soal? 
Siswa Ini kan panjang sisinya bisa didapat

Ekstrovert: dari kelilingnya, terus dari situ dapat dicari luasnya kak.

Peneliti : Lalu?

Siswa Terus ketemu jawaban luas

Ekstrovert: maksimumnya kak

Peneliti: Adakah rencana penyelesaian yang lain?

Siswa Hmmm. tidak kak, saya tidak membuat

Ekstrovert : rencana penyelesaian yang lain, karena saya tidak tahu kalau ada cara yang lain lagi..

Peneliti : $\quad$ Apakah kamu yakin tidak ada informasi yang terlewat dalam soal?

Siswa Yakin kak, yakin.

Dalam membuat perencanaan, siswa ekstrovert dapat memahami bahwa untuk mendapatkan ukuran sisi sisinya, dapat menggunakan bantuan keliling pada bangun segiempat. Kemudian untuk mencari luas, digunakan rumus luas bangun segiempat. Rencana penyelesaian yang digunakan siswa ektrovert yaitu dengan mengaitkan antara informasi dan pengetahuan yang telah dimiliki sebelumnya. Namun, siswa tidak menemukan informasi lain dengan cara menggunakan prosedur non rutin lainnya dalam membuat perencanaan. Siswa yakin rencana penyelesaian yang sudah dibuat menghasilkan jawaban yang tepat. Siswa ekstrovert tidak mampu menemukan informasi yang akan digunakan untuk menjawab pertanyaan dengan tepat, yang berarti siswa tidak memenuhi indikator dalam membuat perencanaan.

Petikan wawancara berikut menunjukkan penjelasan siswa ekstrovert pada tahap melaksanakan perencanaan.

Peneliti : Sekarang jelaskan penyelesaiannya sesuai rencana yang kamu buat tadi!

Siswa Keliling segiempat kan rumusnya $s+$

Ekstrovert : $s+s+s$, atau $4 s$. Nah ketemu sisinya $12.5 \mathrm{~cm}$ kak. Lalu saya mencari luasnya, luas segiempat kan rumusnya sxs, terus saya hitung luasnya sebesar $156,25 \mathrm{~cm}^{2}$.

Peneliti: $\quad$ Apa cuma persegi saya yang kamu gunakan?

Siswa Iya.

Peneliti : Kamu yakin dengan hasil penyelesaian kamu?

Siswa Yakin kak.

Peneliti: Apakah luas yang kamu tuliskan adalah luas maksimum yang diminta pada soal?
Siswa Iya kak, menurut saya itu sudah luas Ekstrovert : maksimum.

Dalam melaksanakan perencanaan, siswa ekstrovert menggunakan informasi yang telah tersedia pada soal. Namun, siswa kurang teliti dalam menyelesaikan masalah sehingga ada informasi yang terlewat dan dapat memengaruhi hasil penyelesaian, yang dibuktikan dengan siswa tidak memperhatikan bahwa yang diminta pada soal adalah sisi dengan bilangan bulat. Siswa tidak memikirkan kembali pertanyaan yang dimaksus pada soal. In'am (2014) mengatakan bahwa ketika siswa tidak membuat perencanaan dengan baik, maka siswa tidak mampu menyelesaikan permasalahan dengan baik pula. Hal tersebut sejalan dengan pendapat Arif (2009) yang mengatakan bahwa siswa yang memiliki kepribadian ekstrovert cenderung tergesa-gesa dalam bertindak dan seringkali ceroboh dalam mengerjakan soal. Siswa ekstrovert tidak memenuhi indikator dalam menyelesaikan masalah dengan baik. Siswa tidak mampu melaksanakan rencana penyelesaian dengan konsep yang sesuai.

Petikan wawancara berikut menunjukkan penjelasan siswa ekstrovert pada tahap memeriksa kembali.

Peneliti : Sudah yakin dengan jawaban kamu?

Siswa Sudah.

Ekstrovert:

Peneliti: $\quad$ Terus apa yang kamu lakukan setelah ketemu jawaban tadi?

Siswa Saya cermati lagi kak, dan saya sudah

Ekstrovert: yakin jawabannya benar. Karena menurut saya, luas dan luas maksimum itu sama, hanya kalimatnya saja yang buat saya bingung. Tapi maksudnya sama aja.

Peneliti: Sudah benar-benar di teliti dari membaca soal sampai ketemu hasil akhirnya?

Siswa Saya baca ulang dari soal sampai Ekstrovert: jawaban kak, saya yakin benar.

Langkah terakhir dalam proses pemecahan masalah adalah kegiatan memeriksa kembali penyelesaian yang telah dituliskan. Siswa tidak melakukan evaluasi jawaban, sehingga siswa tidak menyelesaikan permasalahan yang diberikan secara tepat. Ketika memeriksa jawaban, siswa ekstrovert sangat yakin dan percaya diri terhadap hasil yang telah diperoleh. Hal tersebut sejalan dengan pendapat Jaenudin (2015) bahwa seseorang yang memiliki kepribadian ekstrovert cenderung memiliki sikap percaya diri yang tinggi. Siswa tidak mampu melakukan pengecekan terhadap hasil yang diperoleh untuk memastikan hasil apakah tepat atau 
tidak, yang berarti siswa tidak mampu dalam tahap melaksanakan perencanaan.

Berdasarkan pemecahan masalah yang telah diberikan, siswa ekstrovert tidak mampu melakukan langkah pemecahan masalah dengan benar. Pada awalnya siswa membaca soal untuk memahami masalah, kemudian dilanjutkan dengan membuat strategi perencanaan, melaksanakan perencanaan, dan yang terakhir adalah memeriksa kembali hasil yang diperoleh. Namun pada langkah membuat perencanaan, siswa ekstrovert tidak mampu membuat rencana penyelesaian dengan benar, siswa tidak memperhatikan pada soal bahwa yang diminta adalah panjang sisi dengan bilangan bulat dan yang ditanyakan adalah luas maksimum, sehingga yang tampak pada pola pikir siswa rencana yang telah dibuat sudah benar. Siswa ekstrovert tidak mampu menemukan informasi yang akan digunakan untuk menjawab pertanyaan dengan tepat. Hal tersebut menyebabkan adanya kesalahan dalam memecahkan masalah sehingga hasil yang diperoleh kurang tepat.

2. Profil Kemampuan Pemecahan Masalah Matematika Siswa SMP pada Materi Segiempat Ditinjau dari Tipe Kepribadian Introvert
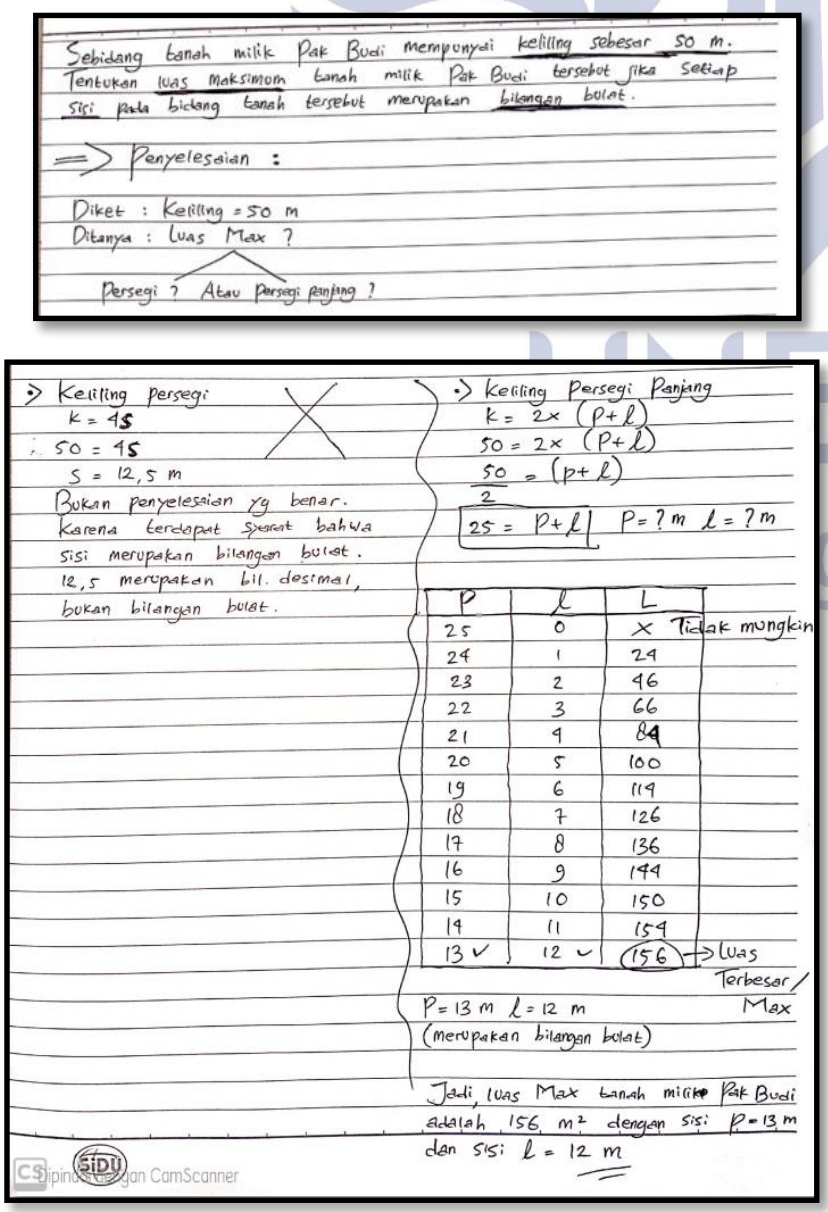

Gambar 2 Hasil Jawaban Siswa Introvert
Petikan wawancara berikut menunjukkan penjelasan siswa introvert pada tahap memahami masalah.

Peneliti : $\quad$ Kamu paham dengan maksud soal itu?

Sswa Awalnya saya kurang paham kak, tapi

Introvert: $\quad$ setelah saya baca ulang jadingerti

Peneliti: Berapa kali kamu membaca untuk memahami?

Siswa

Introvert :

Tiga kali.

Peneliti: Coba jelaskan kembali maksud soal itu!

Siswa Itu diketahui keliling, terus yang

Introvert: ditanyakan luas maksimum. Ini kalau bukan persegi ya persegi panjang kak. Terus saya baca juga, ada syarat kalau sisinya harus bilangan bulat. Itu sudah saya garisbawahi kata yang penting.

Berdasarkan hasil tes dan wawancara yang telah dilakukan, hal pertama yang dilakukan oleh siswa introvert ketika mendapatkan soal berupa masalah matematika yaitu memahami soal dengan membaca secara berulang. Hal tersebut dilakukan siswa introvert agar lebih memahami permasalahan yang diberikan. Siswa mampu menuliskan dan mengungkapkan secara lengkap seluruh informasi yang dianggap penting dari soal yang diberikan. Siswa mampu menuliskan apa yang diketahui, apa yang ditanyakan, serta syarat apa yang dibutuhkan dalam soal tersebut. Siswa introvert dapat menjelaskan bahwa pada soal diminta untuk menentukan luas maksimum jika diketahui kelilingnya. Siswa dapat menyebutkan informasi tambahan yang ada pada soal, bahwa untuk panjang sisinya adalah sebuah bilangan bulat. Jadi dalam memahami masalah, siswa introvert memenuhi indikator mampu menjelaskan apa saja yang diketahui dan ditanyakan dalam masalah tersebut.

Petikan wawancara berikut menunjukkan penjelasan siswa introvert pada tahap membuat perencanaan.

Peneliti : $\quad$ Apa kamu sudah pernah menjumpai soal seperti ini? 
Siswa Kalau yang ditanya luas maksimum

Introvert : belum kak

Peneliti : Dalam menyelesaiakan masalah, kamu menggunakan ide apa saja?

Siswa Saya pakai rumus luas dan keliling

Introvert: seperti yang sudah saya tahu. Untuk mencari sisi, didapat dari keliling. Terus setelah ketemu panjang sisinya, bisa dicari luasnya. Tapi di sini ada dua kemungkinan, kalau tidak persegi ya persegi panjang.

Peneliti: Lalu adakah rencana penyelesaian lain?

Siswa Ada kak. Saya buat dua kemungkinan. Introvert: Bangun mana yang memenuhi syarat, persegi atau persegi panjang. Dari situ nanti bisa dilihat kak, mana yang memenuhi syarat yang diminta di soal.

Peneliti : $\quad$ Apakah kamu yakin tidak ada informasi yang terlewat dalam soal?

Siswa

Introvert : Iya, yakin.

Dalam membuat perencanaan, siswa introvert dapat memahami bahwa untuk mendapatkan ukuran sisi sisinya, dapat menggunakan bantuan keliling pada bangun segiempat. Kemudian untuk mencari luas, digunakan rumus luas bangun segiempat. Siswa juga membuat dugaan apakah bangun yang dimaksud pada soal merupakan persegi atau persegi panjang. Jadi dalam membuat perencanaan, siswa introvert memenuhi indikator mampu menemukan dan memilih informasi-informasi yang akan digunakan untuk menjawab pertanyaan yang ada dengan tepat, serta mampu menjelaskan rencana penyelesaian yang akan dilakukan untuk memecahkan masalah dengan benar.

Petikan wawancara berikut menunjukkan penjelasan siswa introvert pada tahap melaksanakan perencanaan.

Peneliti : Sekarang lo coba penyelesaiannya sesuai rencana yang kamu buat tadi!

Siswa Saya kebetulan mengerjakan Introvert: kemungkinan pertama, yaitu bangun persegi. Saya mencari sisi dari bangun persegi. Ternyata didapat panjang sisinya $12.5 \mathrm{~cm}$, saya beri keterangan bahwa tidak memenui syarat. Saya tidak melanjutkan untuk mencari luas, karena yang diminta pada soal adalah panjang sisinya bilangan bulat.

Peneliti : Lalu?

Siswa Lalu saya lanjutkan ke rencana Introvert: penyelesaian lain, yang bangun persegi panjang. Terus ketemu jumlah sisi panjang dan lebarnya $25 \mathrm{~cm}$. Disitu saya nggak tau kak, berapa panjangnya dan berapa lebarnya.
Peneliti : Lalu apa yang kamu lakukan?

Siswa Nah, dari $25 \mathrm{~cm}$ itu saya buat list kayak

Introvert tabel gitu, untuk mencari berapa luas maksimumnya. Dan setelah saya hitung, luas maksmimumnya $156 \mathrm{~cm}^{2}$, dengan sisi panjangnya $13 \mathrm{~cm}$ dan sisi lebarnya $12 \mathrm{~cm}$.

Peneliti : $\quad$ Kamu yakin dengan hasil penyelesaian kamu?

Siswa Yakin, sudah memenuhi syarat juga.

Introvert :

Peneliti : Apakah luas yang kamu tuliskan adalah luas maksimum yang diminta pada soal?

Siswa Hmmm.. iya kak. Karena luas yang Introvert: paling besar ya itu.

Setelah memilih strategi dalam membuat perencanaan, siswa introvert melanjutkan ke langkah selanjutnya, yaitu melaksanakan perencanaan sesuai dengan strategi perencanaan yang telah dibuat sebelumnya. Siswa memilih strategi apa yang sesuai dengan yang dibutuhkan dalam menyelesaikan masalah. Siswa introvert telah menuliskan penyelesaian masalah dengan rinci dan teliti, selain itu pada saat wawancara siswa juga menjawab pertanyaan peneliti dengan penuh hati-hati, dan memerlukan waktu sejenak untuk berpikir. Hal tersebut sejalan dengan pendapat Arif (2009) yang mengatakan bahwa siswa yang memiliki kepribadian introvert cenderung berhati-hati dan berpikir dalam mengambil setiap keputusan. Siswa introvert memenuhi indikator mampu melaksanakan rencana penyelesaian sesuai dengan strategi yang telah dibuat sebelumnya serta mampu melaksanakan rencana penyelesaian dan konsep yang sesuai.

Petikan wawancara berikut menunjukkan penjelasan siswa introvert pada tahap memeriksa kembali.

Peneliti: Terus apakah kamu yakin dengan jawaban kamu ini?

Siswa $\quad$ Yakin jawabannya $156 \mathrm{~cm}^{2}$.

Peneliti : $\quad$ Kenapa kamu bisa yakin jawaban kamu benar?

Siswa Saya yakinnya dari list tabel saya kak, Introvert: saya juga sudah menghitung ulang. Kalau kelilingnya $50 \mathrm{~cm}$, berarti panjangnya $13 \mathrm{~cm}$, lebarnya $12 \mathrm{~cm}$, itukan sudah bilangan bulat. Terus untuk luas maksimumnya $156 \mathrm{~cm}^{2}$, karena itu luas yang paling besar.

Peneliti: Sudah benar-benar di teliti dari membaca soal sampai ketemu hasil akhirnya?

Siswa Sudah kak, sudah saya baca ulang dari Introvert: $\quad$ soal sampai dapat jawaban. 
Langkah terakhir dalam proses pemecahan masalah adalah kegiatan memeriksa kembali penyelesaian yang telah dituliskan. Ketika memeriksa jawaban, siswa introvert mengecek ulang hasil yang diperoleh serta melakukan evaluasi langkah-langkah penyelesaian. Siswa menuliskan penyelesaian dengan rinci, terstruktur, serta berhatihati. Siswa melakukan perhitungan ulang terkait hasil yang diperoleh untuk memastikan bahwa jawaban yang diperoleh sudah tepat, dalam hal ini siswa tidak tergesa-gesa dalam menyimpulkan jawaban. Hal tersebut sejalan dengan pendapat Jaenudin (2015) bahwa seseorang yang memiliki kepribadian introvert cenderung memiliki sikap tenang dan lebih sabar ketika menghadapi suatu masalah. Ketika peneliti menanyakan kebenaran terhadap hasil yang telah dikerjakan, siswa dapat membuktikan kebenarannya. Sesuai dengan pendapat Fajriah dkk (2016), bahwa siswa mempunyai kemampuan pemecahan masalah yang baik apabila mampu memeriksa kebenaran hasil jawaban yang dilakukan ketika menyelesaikan suatu permasalahan. Siswa introvert memenuhi indikator bahwa mampu melakukan pengecekan kembali atas hasil yang telah diperoleh untuk memastikan penyelesaian tersebut tepat atau tidak.

Berdasarkan pemecahan masalah yang telah diberikan, siswa introvert mampu melakukan langkah pemecahan masalah dengan benar, sehingga memperoleh hasil sesuai dengan yang diharapkan Pada awalnya siswa membaca soal untuk memahami masalah, kemudian dilanjutkan dengan membuat strategi perencanaan, melaksanakan perencanaan, dan yang terakhir yaitu memeriksa kembali hasil yang telah diperoleh sebagai kegiatan refleksi.

\section{PENUTUP}

Simpulan

Adapun simpulan mengenai profil kemampuan pemecahan masalah matematika siswa SMP pada materi segiempat ditinjau dari tipe kepribadian ekstrovert-introvert berdasarkan langkah pemecahan masalah Polya yaitu sebagai berikut.

\section{a. Profil Kemampuan Pemecahan Masalah Matematika Siswa SMP pada Materi Segiempat Ditinjau dari Tipe Kepribadian Ekstrovert}

Siswa SMP dengan tipe kepribadian ekstrovert tidak mampu melakukan keseluruhan tahapan dalam menyelesaikan permasalahan. Siswa hanya mampu pada langkah memahami masalah, siswa ekstrovert mampu menjelaskan apa yang diketahui dan ditanyakan. Namun dalam membuat perencanaan, siswa ekstrovert tidak mampu menemukan informasi yang akan digunakan untuk menjawab pertanyaan dengan tepat. Siswa ekstrovert juga tidak mampu melaksanakan rencana penyelesaian dengan konsep yang sesuai. Siswa tidak mampu melakukan pengecekan kembali atas hasil yang telah diperoleh untuk memastikan penyelesaian tersebut tepat atau tidak. Siswa dikatakan tidak mampu dalam menyelesaikan permasalahan jika siswa tidak mampu dalam memahami dan membuat perencanaan masalah dengan baik.

b. Profil Kemampuan Pemecahan Masalah Matematika Siswa SMP pada Materi Segiempat Ditinjau dari Tipe Kepribadian Introvert

Siswa SMP dengan tipe kepribadian introvert mampu melakukan seluruh tahapan dalam menyelesaikan permasalahan. Pada langkah memahami masalah, siswa introvert mampu menjelaskan apa yang diketahui dan ditanyakan dalam masalah. Kemudian dalam membuat perencanaan, siswa introvert memenuhi indikator mampu menemukan dan memilih informasi-informasi yang digunakan untuk menjawab pertanyaan dengan tepat, serta mampu menjelaskan rencana penyelesaian yang akan dilakukan untuk memecahkan masalah dengan benar. Siswa introvert juga mampu melaksanakan rencana penyelesaian sesuai dengan strategi dengan menggunakan konsep yang sesuai. Siswa introvert mampu melakukan pengecekan kembali atas hasil yang telah diperoleh untuk memastikan penyelesaian tersebut tepat atau tidak. Siswa dikatakan mampu dalam menyelesaikan permasalahan jika siswa mampu memahami dan membuat perencanaan masalah dengan baik.

\section{Saran}

Berdasarkan hasil penelitian dan simpulan, peneliti memberikan saran yaitu bagi guru, sebaiknya membiasakan siswa dengan memberikan soal pemecahan masalah matematika. Terutama bagi siswa yang berkepribadian ekstrovert, agar siswa dapat mengembangkan kemampuan pemecahan masalah dengan baik.

\section{DAFTAR PUSTAKA}


Arif, Muhammad. 2009. Proses Berpikir Siswa dalam Menyelesaikan Soal Turunan Fungsi Ditinjau dari Perbedaan Kepribadian dan Kemampuan Matematika. Tesis tidak dipublikasikan. Universitas Negeri Surabaya.

Djaali. 2014. Psikologi Pendidikan. Jakarta: Bumi Aksara.

Fajriah, dkk. 2016. “Analisis Kemampuan Problem Solving dalam Menyelesaikan Materi Aritmetika Sosial Siswa Kelas VII SMP Negeri 7 Banda Aceh Tahun Ajaran 2015/2016". Jurnal Ilmiah Mahasiswa Pendidikan Matematika. Vol. 1 (1): hal. 30-39.

In'am, Akhsanul. (2014). "The Implementation of the Polya Method in Solving Euclidean Geometry Problems". International Education Studies. Vol. 7 (7): pp 149-158.

Isroil, A., Budayasa, I.K., dan Masriyah. 2017. "Profil Berpikir Siswa SMP dalam Menyelesaikan Masalah Matematika Ditinjau dari Kemampuan Matematika”. Jurnal Review Pendidikan Matematika. Vol. 2 (2): hal.93-105.

Jaenudin, Ujam. 2015. Dinamika Kepribadian. Bandung: CV Pustaka Setia.

Mudrika, Nafis. 2011. Membaca Kepribadian Menggunakan Tes MBTI (Myer Briggs Type Indicator),(Online),(http://nafismudrika/2011/02/18/ mbti.pdf, diakses pada 3 April 2020).

Polya, G. 1973. How to Solve it: A new aspect of mathematical method. USA: Princeton University Press.
Rahma, F. \& Masriyah. 2016. "Profil Pemecahan Masalah Matematika Siswa dalam Menyelesaikan Soal Cerita Ditinjau dari Perbedaan Jenis Kelamin”. Jurnal Ilmiah Pendidikan Matematika. Vol.2 (5): hal. 81-89.

Reys, Robert E. 1978. Helping Children Learn Mathematics. New Jersey: Prentice Hall.

Riyeni, C. \& Khabibah, S. 2017. "Profil Pemecahan Masalah Matematika Siswa SMP Materi Bangun Datar Ditinjau dari Tipe Kepribadian”. Jurnal Ilmiah Pendidikan Matematika. Vol. 3 (6): hal. 31-36

Shadiq, Fajar. 2004. Pemecahan Masalah, Penalaran, dan Komunikasi dalam Pembelajaran Matematika. Depdiknas. Dirjen Pendidikan Dasar dan Menengah Pusat Pengembangan Penataran Guru (PPPG) Matematika. Yogyakarta.

Siskawati, Fury Styo. 2013. Penalaran Siswa SMP dalam Memecahkan Masalah Matematika Ditinjau dari Perbedaan Kepribadian Ekstrovert dan Introvert. Tesis tidak dipublikasikan. Universitas Negeri Surabaya.

Siswono, Tatag Y. E. 2018. Pembelajaran Berbasis Pengajuan dan Pemecahan Masalah. Bandung: Rosdakarya.

Soetopo, Hendyat. 2012. Perilaku Organisasi: Teori dan Praktik di Bidang Pendidikan. Bandung: Remaja Rosdakarya.

Widayanti, Lilis. 2016. "Deskripsi Level Kemampuan Siswa SMP dengan Tipe Kepribadian Cenderung Introvert dalam Menyelesaikan Masalah Matematika”. Jurnal Edukasi. Vol. 2 (1) hal 83-94. 